Б. Д. Махаков, Ю. А. Саранова, Ю. В. Хармаев. К вопросу о повышении уровня прокурорского надзора за исполнением законности органами следствия и дознания при приеме...

УДК: 347.963

Научная статья

DOI 10.18101/2658-4409-2020-3-31-36

\title{
К ВОПРОСУ О ПОВЫШЕНИИ УРОВНЯ ПРОКУРОРСКОГО НАДЗОРА ЗА ИСПОЛНЕНИЕМ ЗАКОННОСТИ ОРГАНАМИ СЛЕДСТВИЯ И ДОЗНАНИЯ ПРИ ПРИЕМЕ, РЕГИСТРАЦИИ И РАЗРЕШЕНИИ СООБЩЕНИЙ О ПРЕСТУПЛЕНИЯХ
}

\section{(c) Махаков Буян Доржиевич}

кандидат юридических наук, доцент, Академия управления МВД России

Россия, 125171, г. Москва, ул. А. и 3. Космодемьянских, 8

m9168156166@yandex.ru

\section{(C) Саранова Юлия Александровна}

младший советник юстиции (в отставке), ассистент, Бурятский государственный университет имени Доржи Банзарова Россия, 670000, г. Улан-Удэ, ул. Сухэ-Батора, 6

yulia1704@bk.ru;

\section{(C) Хармаев Юрий Владимирович}

кандидат юридических наук, доцент, Бурятский государственный университет имени Доржи Банзарова Россия, 670000, г. Улан-Удэ, ул. Сухэ-Батора, 6

kharmaev@mail.ru

\begin{abstract}
Аннотация. В настоящей статье авторы в качестве предмета исследования определяют соблюдение прав и свобод человека и гражданина в уголовном судопроизводстве, точнее, роль органов прокуратуры при проведении надзорных мероприятий с целью устранения нарушений законности со стороны органов дознания и предварительного следствия при приеме, регистрации, проверке и разрешении сообщений о преступлениях. Уполномоченными правоохранительными органами должны четко выполняться условия реального соблюдения и уважения основных прав и свобод граждан; принцип законности в уголовном судопроизводстве не должен подменяться никакими другими принципами ради достижения сиюминутных целей. Авторы в ходе изучения проблемы использовали диалектический подход к объяснению предмета исследования, который позволил им сделать выбор в пользу следующих методов: сравнительно-правовой, статистический, документальный.
\end{abstract}

Ключевые слова: защита прав и свобод; прокурорский надзор; конституционные права; учет; укрытие преступлений.

\section{Для цитирования}

Махаков Б. Д., Саранова Ю. А., Хармаев Ю. В. К вопросу о повышении уровня прокурорского надзора за исполнением законности органами следствия и дознания при приеме, регистрации и разрешении сообщений о преступлениях // Вестник Бурятского государственного университета. Юриспруденция. 2020. Вып. 3. С. 31-36.

Согласно данным социологических опросов, проводимых различными государственными и общественными организациями (такими как ВЦИОМ, ФОМ, 
Левада-центр и др.), выделяются наиболее важные для граждан проблемы, которые их беспокоят на данном историческом отрезке. Особый интерес вызывают результаты опроса в эти сложные «пандемические» времена, когда очень многое изменилось в привычном ритме жизни людей, как у нас, так и за рубежом. Если дать условную градацию возможных «страхов» респондентов, то картина складывается следующим образом. Рост цен беспокоит $62 \%$ опрошенных граждан; $44 \%$ респондентов боятся угрожающего обнищания населения, бедности; $41 \%$ интервьюируемых волнует проблема коррупции (по сравнению с прошлым 2019 г. этот показатель повысился на 29\%) [6]. Большую тревогу у граждан вызывает увеличивающееся расслоение бедных и богатых (проблема социального неравенства) - 34\%. $28 \%$ опрошенных граждан обеспокоены несправедливостью при защите своих прав в судебном и административном порядке. Несмотря на пятую позицию в условном рейтинге проблем, волнующих сегодня респондентов, следует признать, что права и свободы граждан в современном государстве являются незыблемыми и должны в полном объеме обеспечиваться государством.

Одним из важнейших механизмов обеспечения прав и свобод граждан является наличие такого института, как органы прокуратуры. Хотелось бы поделиться мнением о роли прокурорского надзора за исполнением законов органами, осуществляющими оперативно-разыскную деятельность, дознание и предварительное следствие. Этим вопросам посвящено немало исследований, существуют различные подходы к совершенствованию деятельности правоохранительных органов и органов прокуратуры $[1$, с. $3 ; 2$, с. $47 ; 3$, с. $58 ; 5$, с. 23$]$.

В XXI в. обязательно следует учитывать те обстоятельства, что население обладает большим объемом информации, который не ограничивается только официальными средствами массовой информации (далее - СМИ), газетами и телевидением. Следует согласиться, что нынешнее молодое поколение практически информацию получают через интернет и социальные сети. В последние годы в стране было немало информационных поводов, чтобы задуматься о проблеме защиты личных прав и свобод граждан, о взаимоотношениях личности и государства, роли и значении правоохранительных органов в сфере противодействия преступности. Достаточно вспомнить нашумевшее «дело Голунова», которое благодаря гражданской позиции журналистского сообщества показало, как не должны работать представители правоохранительных органов ${ }^{1}$. Этот случай и ряд других схожих уголовных дел ${ }^{2}$ отчетливо показывают необходимость реформирования деятельности «силовых» структур и повышения роли прокурорского надзора в контексте защиты прав и свобод граждан [4, с. 278].

Мы прекрасно осознаем, что нормативно отечественным законодательством урегулированы формы и методы прокурорского реагирования на нарушения законности, от кого бы то это ни исходило. В соответствии с Федеральным законом «О прокуратуре РФ» от 17.01.1992 г. № 2202-1 и другими нормативно-правовыми актами органы прокуратуры наделены обширными полномочиями при соблюдении законности в стране.

\footnotetext{
${ }^{1}$ Как дело Голунова отразится на доверии к полиции [Электронный ресурс] // BFM.RU. URL: https://www.bfm.ru/news/416471 (дата обращения: 09.09.2020).

2 Журналист Николай Ярст рассказал о сходстве своего дела с историей Голунова [Электронный ресурс] // BFM.RU. URL: https://www.bfm.ru/news/416461 (дата обращения: 09.09.2020).
} 
Б. Д. Махаков, Ю. А. Саранова, Ю. В. Хармаев. К вопросу о повышении уровня прокурорского надзора за исполнением законности органами следствия и дознания при приеме...

Прокурор, реализуя предоставленные ему ст. 37 Уголовно-процессуального кодекса Российской Федерации (далее - УПК РФ) и иные предусмотренные уголовно-процессуальным законом полномочия, обеспечивает и осуществляет постоянный надзор за исполнением органами дознания и предварительного следствия требований УПК и иных федеральных законов при приеме, регистрации, проверке и разрешении сообщений о преступлениях.

В соответствии с приказом генерального прокурора Российской Федерации от 05.09.2011 г. № 277 «Об организации прокурорского надзора за исполнением законов при приеме, регистрации и разрешении сообщений о преступлениях в органах дознания и предварительного следствия» работники прокуратуры мерами прокурорского надзора осуществляют своевременное предупреждение, выявление и устранение нарушений законов в деятельности органов дознания и предварительного следствия, защиту прав и законных интересов лиц, пострадавших от преступлений, пресекают незаконные действия (бездействие) и решения должностных лиц названных органов, препятствующие доступу пострадавших от преступлений к уголовному судопроизводству ${ }^{1}$.

Надзорная практика показывает, что состояние законности в указанном направлении не в полной мере соответствует требованиям уголовно-процессуального законодательства, ведомственных и межведомственных нормативно-правовых актов, в том числе межведомственному приказу генерального прокурора Российской Федерации, МВД России, МЧС России, Минюста России, ФСБ России, Минэкономразвития России, ФСКН России от 29.12.2005 г. № 39/1070/1021/253/780/353/399 «О едином учете преступлений».

Согласно статистическим данным, размещенным на официальном сайте Генеральной прокуратуры Российской Федерации, прокурорами при осуществлении надзора за исполнением органами предварительного расследования уголовно-процессуального законодательства при приеме, регистрации и разрешении сообщений о преступлениях в 2019 г. выявлено 3627932 нарушения закона (в 2018 г. $3730794)^{2}$. В целом за весь 2019 г. по стране было совершено 2024300 преступлений, что на 1,6\% больше, чем за аналогичный период 2018 г. (за январь-декабрь 2018 г. совершено 1992000 преступлений) ${ }^{3}$. Как показывают статистические данные, нарушений выявлено почти в полтора раза больше, чем зарегистрировано преступлений. Прокуратурой Республики Бурятия в рассматриваемой сфере в 2019 г. выявлено 13413 нарушений (в 2018 г. - 15 802)4.

Особого внимания заслуживает спектр выявляемых прокурорами нарушений в сфере учетно-регистрационной дисциплины. Пресекаются факты необоснованного продления сроков и безосновательного проведения процессуальных проверок,

\footnotetext{
${ }^{1}$ П. 1 приказа генерального прокурора Российской Федерации от 05.09.2011 г. № 277 «Об организации прокурорского надзора за исполнением законов при приеме, регистрации и разрешении сообщений о преступлениях в органах дознания и предварительного следствия» // Законность. 2011. № 12.

${ }^{2}$ Статистические данные об основных показателях деятельности органов прокуратуры Российской Федерации за январь-декабрь 2019 г. Генеральная прокуратура Российской Федерации. URL: https:/genproc.gov.ru/stat/data/1795898/ (дата обращения: 09.09.2020).

3 Состояние преступности в России. За январь — декабрь 2019 г. / Министерство внутренних дел РФ. ФКУ «Главный информационно-аналитический центр». URL: https:// xn--b1aew.xn--p1ai/reports/2/ (дата обращения: 09.09.2020).

${ }^{4}$ Результаты деятельности органов прокуратуры РФ. Прокуратура Республики Бурятия. URL: https://epp.genproc.gov.ru/web/proc_03/activity/statistics/office/result (дата обращения: 09.09.2020).
} 
направления сообщений о преступлении по подследственности при отсутствии для этого оснований, незаконного списания сообщений о преступлениях в номенклатурное дело, неуведомления заявителей о принятых решениях и иные нарушения закона.

Надзорная практика показывает, что руководителями органов дознания полномочия по изучению материалов проверок до принятия процессуальных решений надлежащим образом не исполняются, письменные указания о проведении конкретных проверочных действий в целях установления имеющих значение обстоятельств даются крайне редко, что отрицательно сказывается на сроках процессуальных проверок, продление которых до 10 суток зачастую осуществляется при отсутствии фактических обстоятельств, препятствующих принятию процессуального решения.

Как показывают материалы проверок, зачастую органы дознания (в большинстве участковые уполномоченные полиции) заняты в своей деятельности несвойственными функциями. Например, в нарушение названных норм уголовного и уголовно-процессуального законодательства ими проверяются заявления о нарушении порядка в подъездах домов, доставке товара не по надлежащему адресу, иные, подлежащие приобщению к специальному номенклатурному делу либо рассмотрению в соответствии с Федеральным законом от 02.05.2006 г. № 59-Ф3 «О порядке рассмотрения обращений граждан Российской Федерации».

Распространены факты безосновательного проведения органами дознания проверок в порядке ст. 144-145 УПК РФ по сообщениям, изначально не содержащим сведений о преступлениях. В соответствии со ст. 144 УПК РФ дознаватель, орган дознания обязаны принять, проверить сообщение о любом совершенном или готовящемся преступлении, понятие которого определено ст. 14 Уголовного кодекса Российской Федерации.

Безосновательное проведение доследственных проверок не отвечает назначению уголовного судопроизводства, влечет за собой излишнюю нагрузку на сотрудников правоохранительных органов, отвлечению их от реализации возложенных задач.

При этом, несмотря на наличие очевидных признаков уголовно наказуемого деяния, повода и основания для начала процедуры уголовного преследования, принимаются незаконные решения об отказе в возбуждении уголовного дела. Зачастую указанные процессуальные решения выносятся немотивированно, без учета фактических данных и проведения мероприятий, направленных на установление юридически значимых обстоятельств.

Вынесение незаконных процессуальных решений об отказе в возбуждении уголовных дел по п. 1, 2 ч. 1 ст. 24 УПК РФ является наиболее распространенным способом укрытия преступлений от учета. Незаконное и необоснованное принятие решений об отказе в возбуждении уголовного дела в первую очередь влечет нарушение прав участников уголовного судопроизводства на доступ к правосудию в разумный срок.

В целях обеспечения участникам уголовного судопроизводства права на защиту, а также на доступ к правосудию в разумный срок прокуроры отменяют незаконные постановления органов предварительного расследования. При этом одним из наиболее эффективных методов является встречный опрос граждан, предусмотренный п. 1.2 приказа генерального прокурора от 05.09.2011 г. № 277 «Об 

надзора за исполнением законности органами следствия и дознания при приеме...

организации прокурорского надзора за исполнением законов при приеме, регистрации и разрешении сообщений о преступлениях в органах дознания и предварительного следствия», в ходе которого обязательно проверяется, не использовались ли по отношению к заявителю, изменившему свое первичное обращение или объяснение, незаконные методы воздействия.

По данным Генеральной прокуратуры Российской Федерации, в 2019 г. прокурорами отменено 2035927 незаконных постановлений об отказе в возбуждении уголовного дела (в 2018 г. - 2225 641) ${ }^{1}$. Как показывает практика, значительная часть из них отменяется прокурорами неоднократно.

Всего в 2019 г. после отмены прокурорами постановлений об отказе в возбуждении уголовного дела зарегистрировано 162445 уголовных дел (в 2018 г. 165 646). В 2019 г. прокурорами Республики Бурятия с учетом повторных отменено 7921 решение органов следствия и дознания об отказе в возбуждении уголовного дела (в 2018 г. - 11 851). После отмены таких решений в 2019 г. возбуждено 1062 уголовных дела (в 2018 г. - 1321$)^{2}$. Тогда как за весь 2019 г. по Республике Бурятия зарегистрировано 22124 преступления, что меньше на 5,9\%, чем за аналогичный период 2018 г. Всего за январь-декабрь 2018 г. на территории Республики Бурятия зарегистрировано 23511 преступлений ${ }^{3}$.

Распространенность нарушений в анализируемой сфере не только требует от прокуроров применения всего комплекса полномочий, но и обеспечение органами следствия и дознания неукоснительного исполнения уголовно-процессуального законодательства, межведомственных и ведомственных нормативных правовых актов, регламентирующих организацию приема, регистрации и разрешения сообщений о преступлениях.

В заключение отметим, что соблюдение прав, свобод и законных интересов граждан в любой стране - это визитная карточка, показатель социального благополучия и качества жизни граждан. В целях построения правового государства и реального соответствия принципам реализации основных прав и свобод конкретной личности в обществе возникает необходимость не только документально в нормативно-правовых источниках, но и в объективной реальности подтвердить приверженность к демократическим началам.

\section{Литература}

1. Атмажитов В. М., Бобров В. Г. Еще раз о нормативном правовом регулировании прокурорского надзора за оперативно-разыскной деятельностью // Оперативник (сыщик). 2011. № 4. С. 3-5.

2. Железняков Ю. Г. Особенности прокурорского надзора за оперативноразыскной деятельностью // Запад - Россия - Восток. Археология. История. Философия. Юриспруденция. 2013. № 3-4. С. 47-51.

${ }^{1}$ Статистические данные об основных показателях деятельности органов прокуратуры Российской Федерации за январь-декабрь 2019 г. Генеральная прокуратура Российской Федерации. URL: https://genproc.gov.ru/stat/data/1795898/ (дата обращения: 09.09.2020).

${ }^{2}$ Результаты деятельности органов прокуратуры РФ. Прокуратура Республики Бурятия. Раздел 2 отчета прокуратуры Республики Бурятия о результатах надзора на досудебной стадии уголовного судопроизводства по форме НСиД за 12 месяцев 2018 г. и 12 месяцев 2019 г. URL: https://epp.genproc.gov.ru/web/proc_03/ᄀactivity/-statistics/office/result (дата обращения: 09.09.2020).

3 В МВД по Республике Бурятия состоялось заседание коллегии по итогам работы за 2019 г. URL: https://xn--b1aew.xn--p1ai/reports/2/ (дата обращения: 09.09.2020). 
3. Кожевников О. А. Полномочия прокурора в надзоре за законностью оперативно-разыскной деятельности // Вестник Кемеровского государственного университета. Сер. Гуманитарные и общественные науки. 2018. № 3. С. 58-63.

4. Хармаев Ю. В. ФЗ «О полиции» и современные проблемы ОВД // Вестник Бурятского государственного университета. 2014. Вып. 2. С. 278-279.

5. Хармаев Ю. В. Теория оперативно-разыскной деятельности: учеб. пособие. Улан-Удэ: Изд-во ВСГУТУ, 2015. 152 с.

6. Шамардина Л. За бедностью следует коррупция [Электронный ресурс] // Коммерсантъ. 2019. № 35. URL: https://www.kommersant.ru/doc/3895677 (дата обращения: 09.09.2020).

\section{ON INCREASING THE LEVEL OF PROSECUTORIAL SUPERVISION OVER THE EXECUTION OF LEGALITY BY THE BODIES OF INVESTIGATION AND INQUIRY WHEN RECEIVING, REGISTERING AND RESOLVING REPORTS OF CRIMES}

Buyan D. Makhakov

Cand. Sci. (Law), A/Prof., Academy of Management of the Ministry of Internal Affairs of Russia, 8 A. and Z. Kosmodemyanskikh St., Moscow 125171, Russia m9168156166@yandex.ru

Yulia A. Saranova

Junior Counselor of Justice (retired), Assistant, Dorzhi Banzarov Buryat State University, 6 Sukhe-Batora St., Ulan-Ude 670000, Russia yulia1704@bk.ru;

Yury V. Kharmaev

Cand. Sci. (Law), A/Prof., Dorzhi Banzarov Buryat State University, 6 Sukhe-Batora St., Ulan-Ude 670000, Russia kharmaev@mail.ru

Abstract. In the article, the authors define as the subject of research the observance of human and civil rights and freedoms in criminal proceedings, more precisely, the role of the prosecutor's office in carrying out supervisory measures to eliminate violations of the law by the bodies of inquiry and preliminary investigation when receiving, registering, checking and resolving messages about crimes. The authorized law enforcement agencies must clearly comply with the conditions for real observance and respect for the fundamental rights and freedoms of citizens; the principle of legality in criminal proceedings should not be replaced by any other principles in order to achieve momentary goals. In the course of studying the problem, the authors used a dialectical approach to explaining the subject of research, which allowed them to make a choice in favor of the following methods: comparative legal, statistical, documentary.

Keywords: protection of rights and freedoms, prosecutor's supervision, constitutional rights, accounting, crime concealment.

Статья поступила в редакцию 25.09.20; одобрена после редактирования 01.11.20; принята к публикации 05.11.20. 